\title{
Electron Microscope Study on the Embryonic Differentiation of the Epidermis in Human Skin*
}

\author{
Hidesuke Fujita, Chidori Asagami, Yoshihiko Oda, Keiichiro Yamamoto \\ and Takao UCHIHIRA \\ （藤田英輔, 麻上千鳥, 小田嘉彦, 山本慶一郎, 内平孝雄）
}

Received August 21, 1970

There are several reports of electron microscopic studies on the epidermis of human fetuses and/or embryos: BREATHNACH and WYLLIE (1965 a, 1965 b) reported on the ultrastructure of the epidermis in human fetuses 12 and 14 w eeks of menstrual age: RIEGEL (1965) in human fetuse 25 to $60 \mathrm{~mm}$ long in crown-rump length; HASHIмото et al. (1966) in human fetuses 12 to 22 weeks of menstrual age, 60 to $180 \mathrm{~mm}$ in crown-rump length; Fujita and Asagami (1966) in human embryos and fetuses 6 weeks to 34 weeks of menstrual age, $5 \mathrm{~mm}$ in total length to $42 \mathrm{~mm}$ in foot length; Hoyes $(1967,1968)$ in human fetuses 8 to 26 weeks of menstrual age, 26 to $230 \mathrm{~mm}$ in crown-rump length.

Hoyes investigated, in the above papers, the epidermis of fetuses 26 to $50 \mathrm{~mm}$ in crown-rump length, as the youngest group, whose menstrual ages were calculated 8 to 11 weeks on the basis of crown-rump length according to the data by AREY (1966). He found that the epidermis in the earliest developmental stage of his materials consisted of two layers of cells, the basal layer and the periderm.

At the Sixth International Congress for Electron Microscopy held in Kyoto, we (Fujita and Asagami, 1966) reported that the epidermis of an embryo $5 \mathrm{~mm}$ in total length whose menstrual age was estimated to be 6 weeks from the data of crownrump length given by NAKAMURA et al. (1955-56), consisted mainly of a single layer of cells. Though it is difficult to make an exact comparison of menstrual age between our embryos and the fetuses observed by Hoyes because of the physical differencese between Japanese and English embryos it is presumed that our embryo estimated to be 6 weeks is younger than Hoyes' calculated as 8 weeks. Therefore, it seems likely that judging from the findings of these two reports, the stage of a single layer epidermis may precede that of a bilayer epidermis, the latter being formed by cell multiplication at about 8 weeks of age.

In the reports on the human embryonic epidermis mentioned above, the earliest epidermal melanocytes are those which were found by НАsнгмото et al. (1966) in the scalp skin of a 12-week-old fetus. The earliest Langerhans cells in the epidermis are those which were found by BREATHNACH and WYLLIE (1965a) in the limb and face skin of a 14 -week fetus.

From these reports, the question arises as to whether or not each of the two types of cells appears in the epidermis of human embryonic skins earlier than the

* This study was supported by the Ministry of Education; Ube Industries, Ltd. and Shiseido Co. 


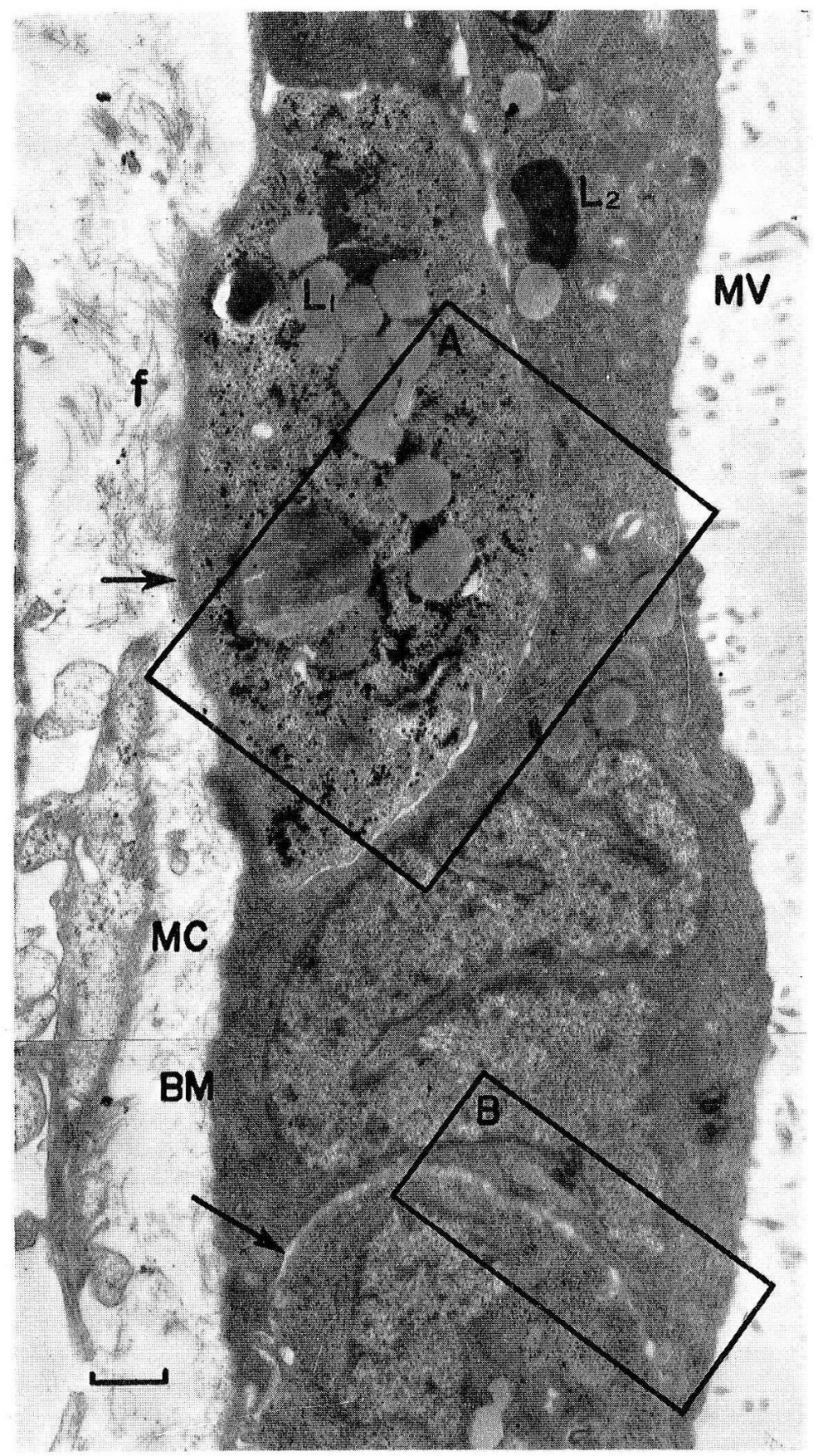

Fig. 1. The epidermis of an embryo estimated to be 6 weeks largcly consists of a single layer, but occasionally of two layers. The majority of cells are oblong in shape and large in size. Their cytoplasm exhibits a relatively high electron density containing abundant free ribosomes. MV numerous microvilli along the amniotic border. $L_{1}$ round bodies of a low electron density probably of a lipid nature. $L_{2}$ electron dense bodies possibly of a lysosomal origin. Arrows indicate cells of different appearance from the majority. $B M$ rudimentary basement membrane to which some collagenous fibrils $(f)$ are attached; formations of half-desmosomes are not evident. $M C$ portion of a mesenchymal cell. $\times 9,200$ 


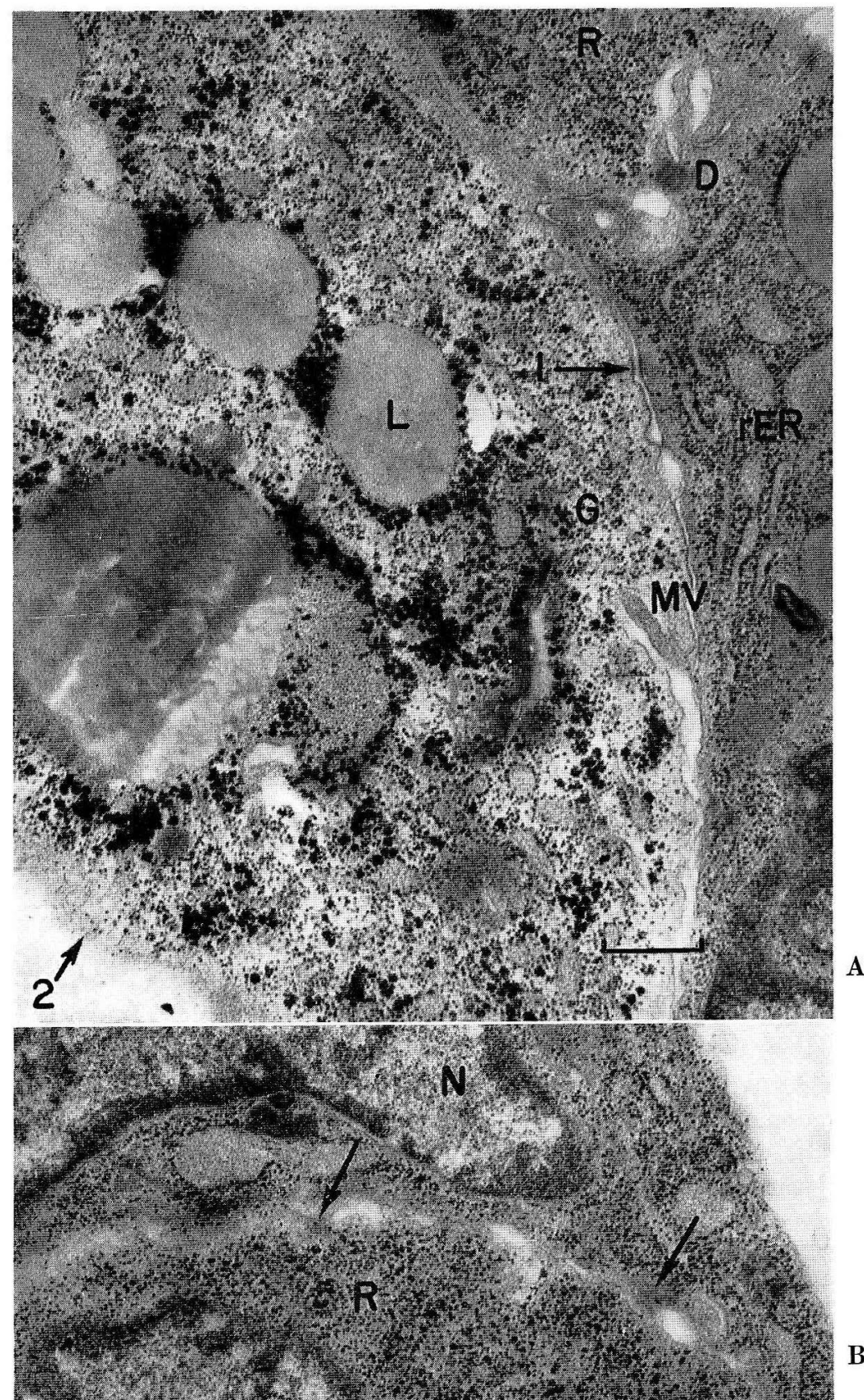

Fig. 1-A. Higher magnification of the area marked by box A. MV a microvillus protruding from the upper cell. $r E R$ well developed rough endoplasmic reticulum. $R$ free ribosomes. $G$ glycogen granules. $L$ round bodies of probable lipid nature. $D$ desmosomes. Arrow 1 indicates a possible desmosome in an incomplete form. Arrow 2 indicates the dermal aspect of the epidermis scarcely underlayed by basement membrane and attached by a few collagenous fibrils. $\times 23,000$

Fig. 1-B. Higher magnification of the area marked by box B. $N$ nucleus. Arrows indicate partially formed desmosomes. $R$ abundant free ribosomes. $\quad \times 23,000$ 
above ages, especially prior to 10 weeks of age. To our knowledge, since 1966 no reports concerning the ultrastructural features of the epidermis of human embryos younger than 8 weeks of age have been reported.

This article deals with the details of our presentation made in Kyoto in 1966 concerning the ultrastructural features of the epidermis from 6 weeks to 10 weeks of age plus findings obtained subsequently on the problems noted above.

\section{Materials and Methods}

Skin specimens were obtained from one embryo estimated to be six weeks of menstrual age, one embryo seven weeks of age, two embryos eight weeks of age, three fetuses nine weeks of age and one fetus ten weeks of age. These embryos and fetuses were obtained from eight freshly aborted Japanese wives. The menstrual age of the embryos and fetuses were calculated from the data of crownrump length given by NAKAMURA et al. (1955-56) and/or from the data of hand breadth and foot length given by Yoshimura (1937). The specimens taken from round slices of the embryos and from the limbs of the fetuses were fixed in 4 to $6.5 \%$ glutaraldehyde for 2 hrs followed by post-fixation in $1 \%$ osmium tetroxide for $1 \mathrm{hr}$. Both fixatives were buffered at $\mathrm{pH} 7.4$ with the phosphate buffer of MiLlONIG (1961). After dehydration in graded ethanol, the materials were embedded in Epon 812 (LuFT, 1961). The sections for electron microscopy were stained with $2 \%$ uranyl acetate and $0.4 \%$ lead citrate. Thick sections (about $1 \mu$ ) were stained in toluidine blue to be examined under the light microscope for orientation and for comparison with the subsequent electron microscopic photographs.

\section{Results}

The epidermis of an embryo ( $5 \mathrm{~mm}$ long in total length), estimated to be 6 weeks menstrual age, ${ }^{*}$ consisted of a single layer in most parts, occasionally two layers, of relatively large oblong cells. The long axis of the cells were in parallel, occasionally oblique, to the rudimentary basement membrane on which they were anchored (Fig. 1). Nuclei usually conformed to the shape of the cell bodies, though a relatively small number were irregularly shaped with deep indentations. A few nuclei had prominently large nucleoli often attached to the nuclear envelope.

The cytoplasm exhibited a relatively high electron density, and abundant free ribosomes, a well developed rough endoplasmic reticulum and numerous mitochondria most of which were closely related to the reticulum. The cisterns of the rough endoplasmic reticulum were mostly flat, but in occasional cells they were dilated and contained fine filamentous substances of a low electron density (Fig. 2). In addition to these cytoplasmic organelles, occasional cells had a well developed Golgi apparatus, numerous densely aggregated membrane-limited small vesicles, many round bodies of a low electron density probably of a lipid nature, electron dense bodies possibly of a lysosomal origin and a relatively small number of dense bodies of an undetermined nature (Fig. 1-A, 1-B, 2).

Mitosis was encountered very rarely in these cells. The cells did not develop tonofilaments, but most of them were connected by a small number of desmosomes seemingly identical with those of adult epidermis, or probable partially formed

\footnotetext{
* This estimation was supported by the information on the last menstrual period of the mother.
} 
desmosomes accompanied by a few tonofilaments (Fig. 1-A). Tripartite junctions were formed between adjacent cells in their apicolateral margins near the amniotic border (Fig. 2). These cells seemed to have passed the first step in the differentiation toward keratinocytes as indicated by the presence of desmosomes along their plasma membranes despite a sparsity of tonofilaments.

There were a small number of cells whose appearances somewhat differed from those of flanking epidermal cells. They were separated by wider intercellular spaces than between other neighboring cells and were not connected by desmosomes

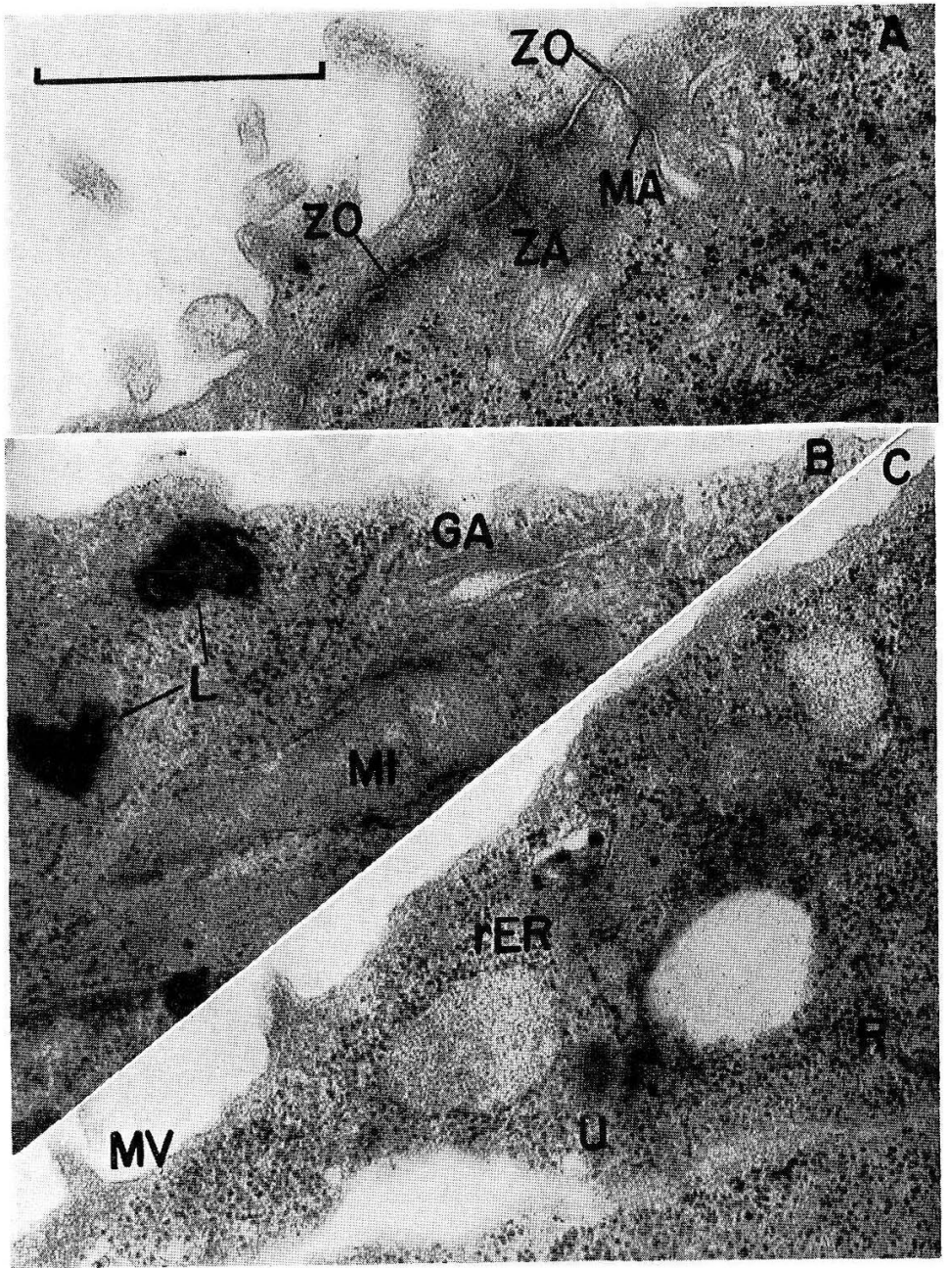

Fig. 2. Portions of a superficial layer cell of the same embryo as in Fig. 1-A. A: $Z O$ zonulae occludentes. $Z A$ zonulae adhaerentes. $M A$ maculae adhaerentes. $\times 30,000$. B: $G A$ well developed Golgi apparatus in the vicinity of amniotic border. $M T$ mitochondria. $L$ electron dense bodies possibly of a lysosomal origin $\times 30,000$. C: $M V$ a microvillus. $\quad r E R$ dilated rough endoplasmic reticulum containing fine filamentous substances. $R$ abundant free ribosomes. $U$ small dense body of an undetermined nature $\times 23,000$ 


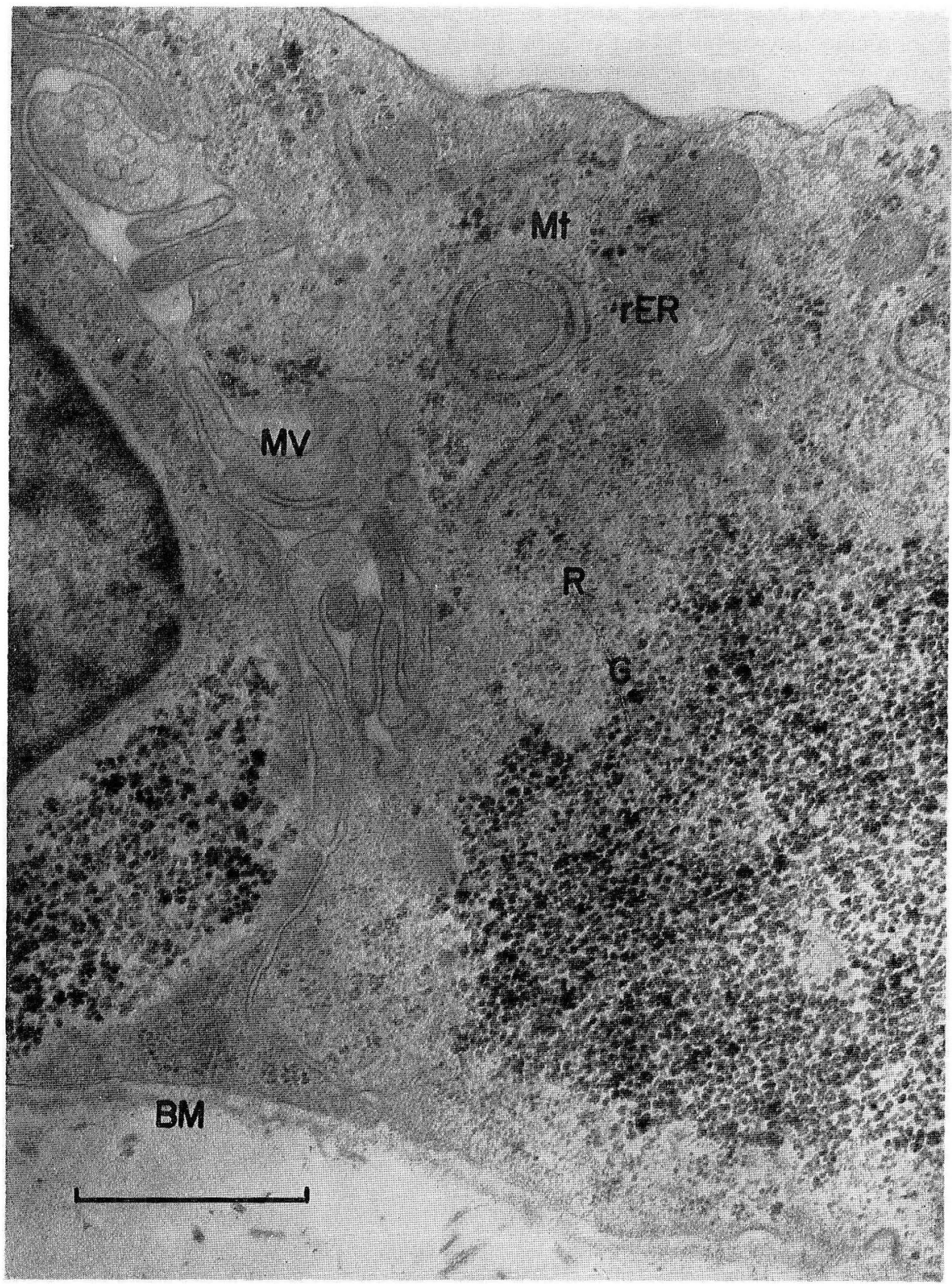

Fig. 3. Single layer portion in the epidermis of a 7-week embryo. The cytoplasm contains numer= ous free ribosomes $(R)$, aggregates of glycogen granules $(G)$, well developed rough endoplasmic reticulum $(r E R)$ and mitochondria $(M t)$. $M v$ microvilli in the intercellular space. $B M$ basement membrane accompanied by a few collagenous fibrils. Formations of half-desmosomes are not evident. 
of a typical appearance. They exhibited a slightly lower electron density of cytoplasm than flanking cells. Except for these differences, their cytoplasm seemed to be nearly identical with that of the above-mentioned differentiating keratinocytes, especially in respect to the morphology of rough endoplasmic reticulum, abundant glycogen granules and many round bodies probably of a lipid nature.

From the absence of desmosomes of typical appearance, the possibility should not be excluded that theses cells may represent melanocytes or Langerhans cells of an undifferentiated type, though their cytoplasm contained no organelles which could be positively identified as either premelanosome, melanosomes or as Langerhans granules. It seems more likely that the section in which the above-mentioned findings were obtained might merely have hit the plane in which these cells had no desmosomes, because of their sparsity.

Intercellular spaces of the epidermis were generally very narrow, but occasionally they were fairly wide and often contained numerous microvilli of the cells. No glycogen granules were recognized in these intercellular spaces. Underlying the dermal aspect of the cytoplasmic membrane of epidermeal cells was the rudimentary basement membrane which was not yet accompanied by evident halfdesmosomes. In most parts a relatively small number of microfibrils or collagenous fibrils were attached to the basement membrane. In some parts, the basement membrane was lacking entirely, and consequently those filamentous structures seemed to be attached directly to the plasma membranes of the stratum germinativum cells (Fig. 1, 1-A).

The amniotic border of the epidermal cells had numerous slender microvilli along their plasma membranes which showed no thickening as yet (Fig. 1, 2).

The epidermis of a 7-week embryo ( $7.2 \mathrm{~mm}$ in total length) consisted of a single layer of cells in most places (Fig. 3) with occasional double layers. The epidermal cells were relatively large in size and cuboidal to oblong in shape, a contrast to the cells of the embryo estimated to be 6 weeks. These cells were densely packed and anchored on the rudimentary basement membrane, being accompanied by no evident half-desmosomes as yet. Intercellular spaces occasionally contained many aggregates of glycogen granules. They were usually narrow bit were quite wide in occasional places where the epidermis consisted of the following two layers of cells: the superficial layer cells were extremely flattened in shape and separated by wide intercellular spaces from the basal layer cells which were connected to the later cells by a few desmosomes and/or zonulae adhaerentes (Fig. 4). These superficial layer cells seemed to be in the process of the formation of periderm; the basal layer cells were cuboidal in shape and seemed to be in the process of the formation of stratum germinativum.

A large number of cells often exhibited prominent, large nucleoli and relatively high electron density of their cytoplasm which contained numerous free ribosomes, concentrated aggregates of abundant glycogen granules, a well developed rough endoplasmic reticulum and mitochondria which were often closely related to the reticulum, but few tonofilaments (Fig. 3).

Interspersed among such cells were found a relatively small number of cells of a different type whose nucleoli were not so large, and whose cytoplasm was evidently less electron dense than that of neighboring cells and showed apparently decreased 
free ribosomes, glycogen granules, clements of rough endoplasmic reticulum and mitochondria (Fig. 5). Notwithstanding these differences, desmosomes of typical appearance were seen between the cells of both types as well as between the first type cells. Therefore, it seemed likely that the two types of cells might represent different stages in the maturation into keratinocytes, the first type representing an

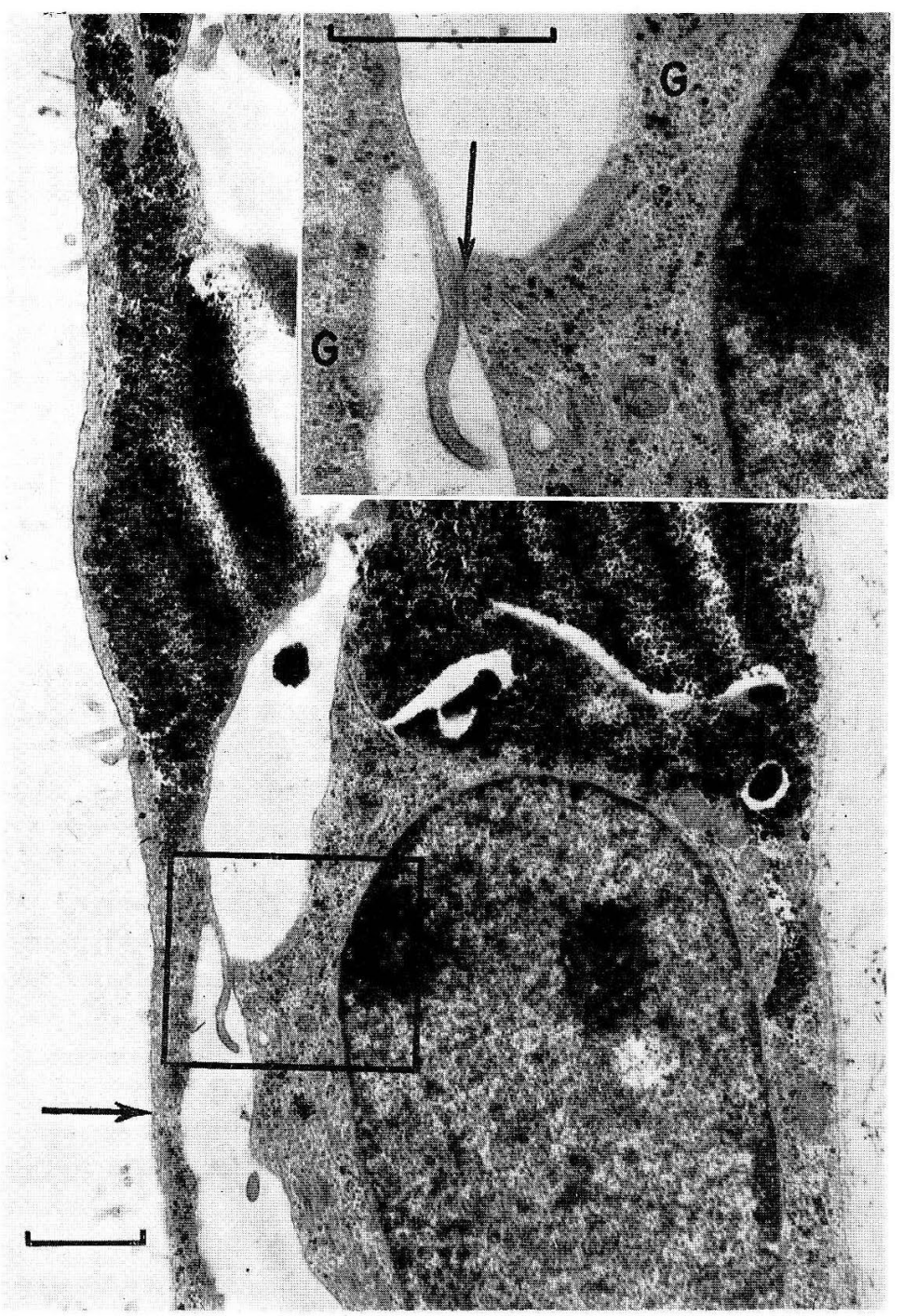

Fig. 4. Low-power view of a double layer portion in the epidermis of the same 7-week embryo as in Fig. 3. The flattened superficial layer cell (arrow) seems to be forming periderm and are separated from the basal layer cells by wide intercellular spaces, $\times 12,900$. Insert: Higher magnification of the area in the box in Fig. 5. Arrow indicates macula adhaerens between the microvillous projections of the presumed periderm cell and the basal layer cell.

$G$ glycogen granules. $\times 25,000$ 


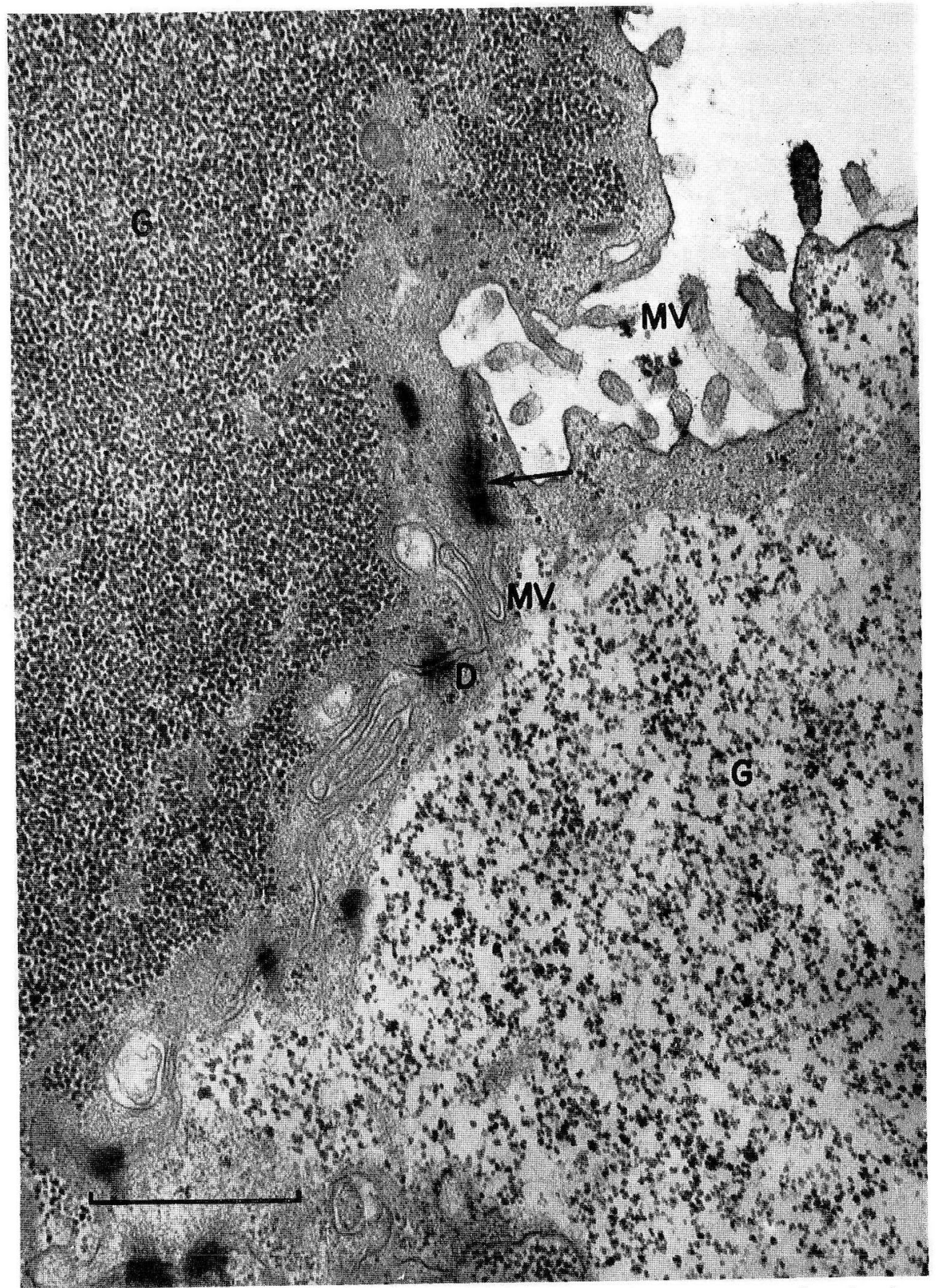

Fig. 5. Two different types of adjoining cells composing the epidermis of the same 7-week embryo in Fig. 3. The cell in the lower right exhibits electron-lucent cytoplasm with sparse free ribosomes, in Fig. 3. The flanking cell. Note the presence of a tripartite junction (arrow) and desmosomes $(D)$ connecting these two types of cells and microvilli $(M V)$ along their surfaces. 
early stage in maturation and the second a more advanced stage. This postulation seems to be suported by the occurrence of more prominent nucleoli, denser cytoplasm and more numerous free ribosomes in the first type cells. A few cells in mitosis were encountered. No cells positively identified either as epidermal melanocytes or as Langerhans cells were found.

As in the 6-week embryo, plasma membranes facing the amniotic cavity were bordered by numerous microvilli and did not seem to be thickened in any places.

The epidermis of two 8-week embryos ( $10 \mathrm{~mm}$ and $12 \mathrm{~mm}$ in crown-rump length) consisted mainly of two layers whose superficial layer seemed to have elevated above the surface. Occasionally the epidermis consisted of a single layer similar in appearance to that of the 7-week-embryo. On the other hand, there were occasional portions stratified into three layers, i e., stratum germinativum, stratum intermedium and periderm; this structure corresponded to the epidermis of the 9 -week fetuses described below.

Most of the bilayer portions were composed of cells which ultrastructurally resembled electron dense type cells in the epidermis of the 7-week embryo but differed from the latter cells in respect to the appearance of rudimentary tonofilaments and the decrease of glycogen granules in their cytoplasm (Fig. 6). Occasionally there were bilayer portions consisting of an electron dense superficial layer and apparently less electron dense basal layer.

The epidermis from the limbs of three 9 -week fetuses ( $12 \mathrm{~mm}$ in crown-rump length, $13 \mathrm{~mm}$ in crown-rump length and $2.5 \mathrm{~mm}$ in hand breadth*) consisted of one layer of stratum germinativum, one to two layers of stratum intermedium and one layer of periderm (Fig. 7). But in some places, it consisted of only two layers of cells, stratum germinativum and presumed periderm without formation of stratum intermedium.

Stratum germinativum cells were densely packed, mostly round to ovoid in shape and usually small but occasionally very large in size. Their cytoplasm mostly exhibited a relatively high electron density containing abundant free ribosomes and $\alpha$-type glycogen granules. Occasional portions of the stratum germinativum consisted predominantly of cells with cytoplasm apparently less electron dense containing only sparsely dispersed glycogen granules, rough endoplamic reticulum and mitochondria in contrast to the above electron dense type cells. In such portions, not only stratum germinativum but also its upper strata including periderm, consisted predominently of less electron dense type cells.

The stratum germinativum cells were anchored to the relatively flat basement membrane without formations of half-desmosomes, hair germs or associated anlages of dermal papillae. The cytoplasm of occasional stratum germinativum cells exhibited rather numerous tonofilaments which were often attached to the plasma membrane opposed to the basement membrane, forming electron dense marginal zones distinct from the other portion of the cytoplasm (Fig. 7-A).

Intercellular spaces between adjacent stratum intermedium cells and between these and periderm cells were relatively widened being connected by a few desmosomes and/or zonulae adhaerentes and divided into compartments by numerous

* The age of the fetus $2.5 \mathrm{~mm}$ in hand breadth was confirmed by the data on the last menstrual period of the mother. 
microvilli. These spaces occasionally contained glycogen granules (Fig. 7-B). Such glycogen granules occurred also in the cytoplasmic matrix and smooth surfaced vacuoles of the cells.

There was a single cell which was located among stratum intermedium cells.

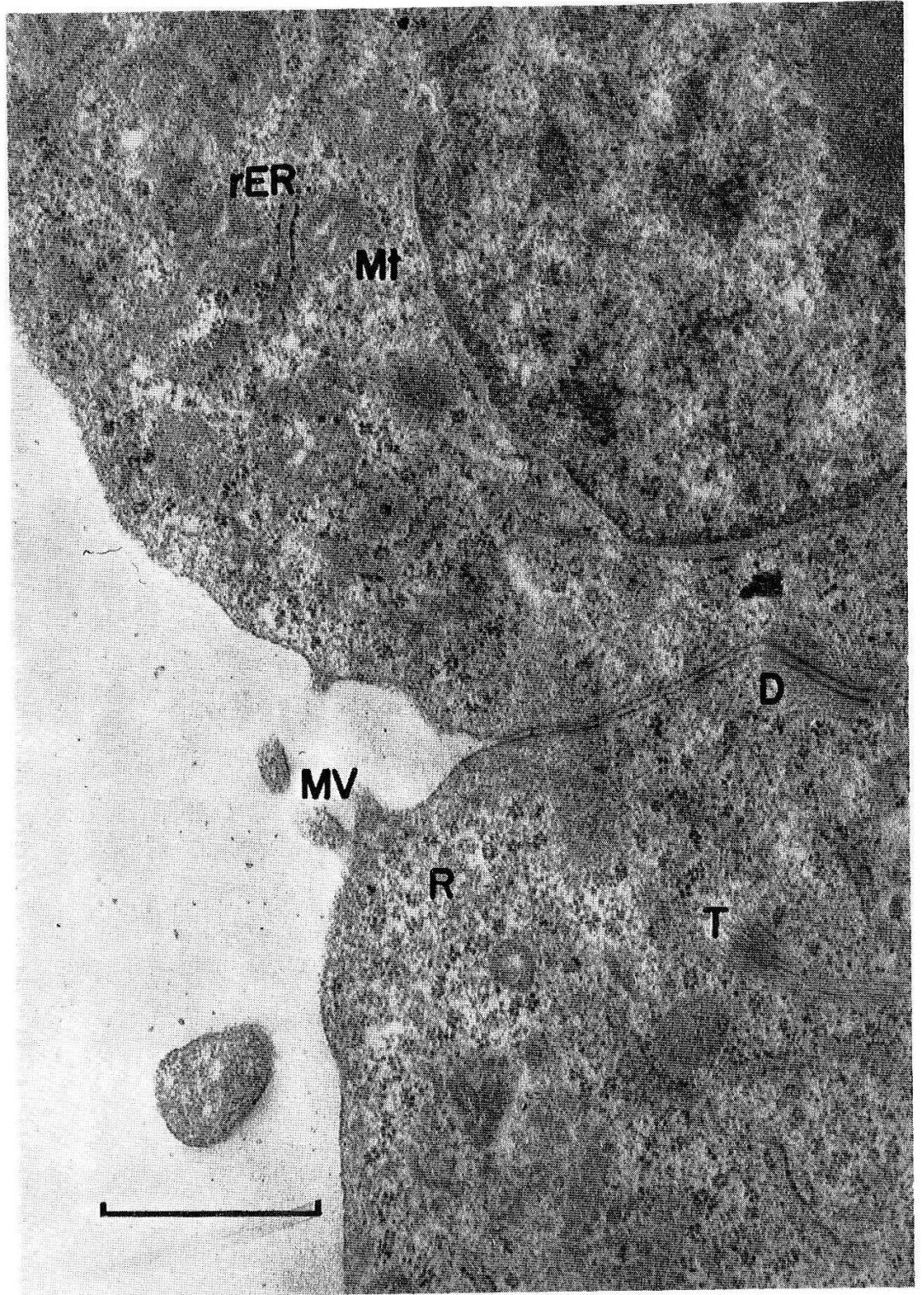

Fig. 6. Superficial layer of a bilayer portion of an 8-week fetus. The ccll on the right hand shows a tendency of elevation above the amniotic surface. A well developed rough endoplasmic reticulum $(r E R)$ and numerous free ribosomes $(R)$ are distributed throughout the cytoplasm. T probable tonofilaments. $M t$ mitochondria. $D$ a fully developed desmosome. $M V$ microvilli along the amniotic border. $\times 26,000$ 
Though the cell differed from the ordinary epidermal melanocyte, it was positively indentified as a melanocyte because of the presence of many premelanosome of different grades of melanization and the absence of Langerhans granules in its cytoplasm (Fig. 8).

It should be noted that this cell corresponds to the earliest epider mal melanocyte which Fujita and his associates (1968) found in the limb skin of a 9-week fetus. Its cytoplasm contained neither tonofilaments nor tonofibrils and exhibited a

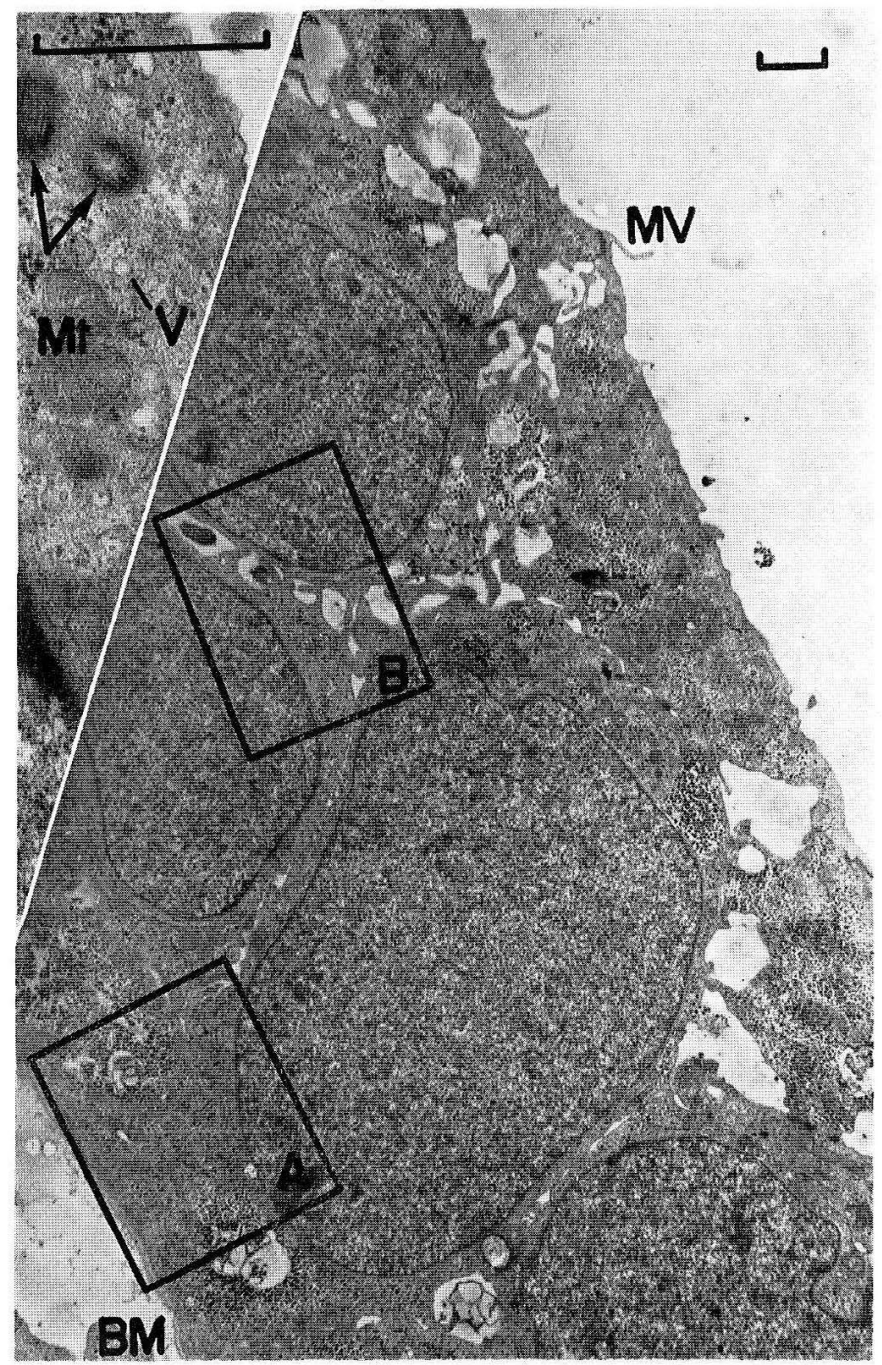

Fig. 7. Low-power view of a portion of the epidermis in limb skin of a 9 -week fetus. The epidermis shows the stratification into periderm, stratum intermedium and stratum germinativum. $M V$ microvilli along the amniotic border, $B M$ basement membrane. $\times 6,000$ Insert: Diplosomes (arrows) in the periderm cell. $V$ a group of membrane-limited small vesicles. $M t$ mitochondria. $\times 20,000$ 

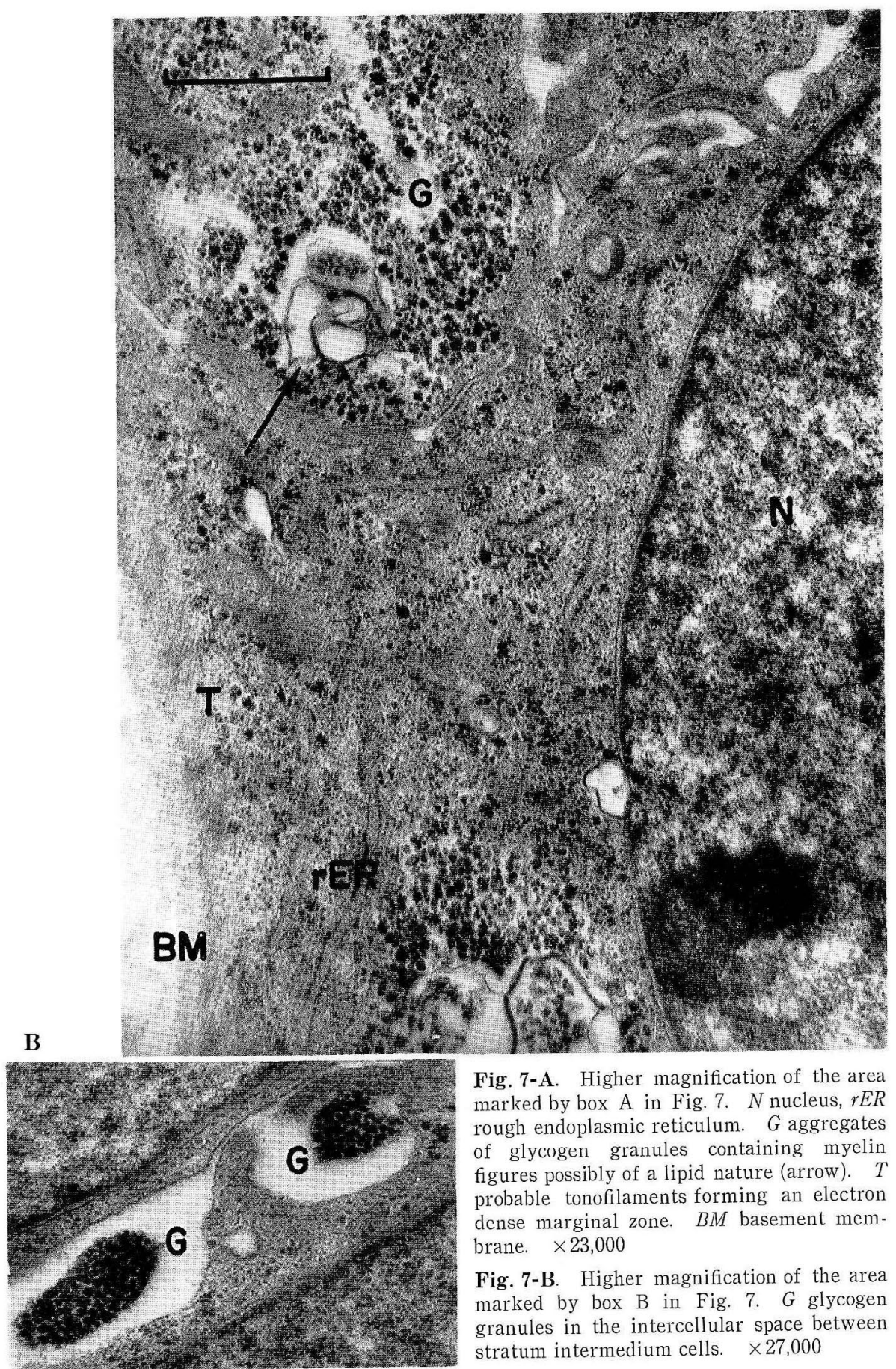

Fig. 7-A. Higher magnification of the area marked by box A in Fig. 7 . $N$ nucleus, $r E R$ rough endoplasmic reticulum. $G$ aggregates of glycogen granules containing myelin figures possibly of a lipid nature (arrow). $T$ probable tonofilaments forming an electron dense marginal zone. $B M$ basement membrane. $\times 23,000$

Fig. 7-B. Higher magnification of the area marked by box B in Fig. 7. G glycogen granules in the intercellular space between stratum intermedium cells. $\times 27,000$ 


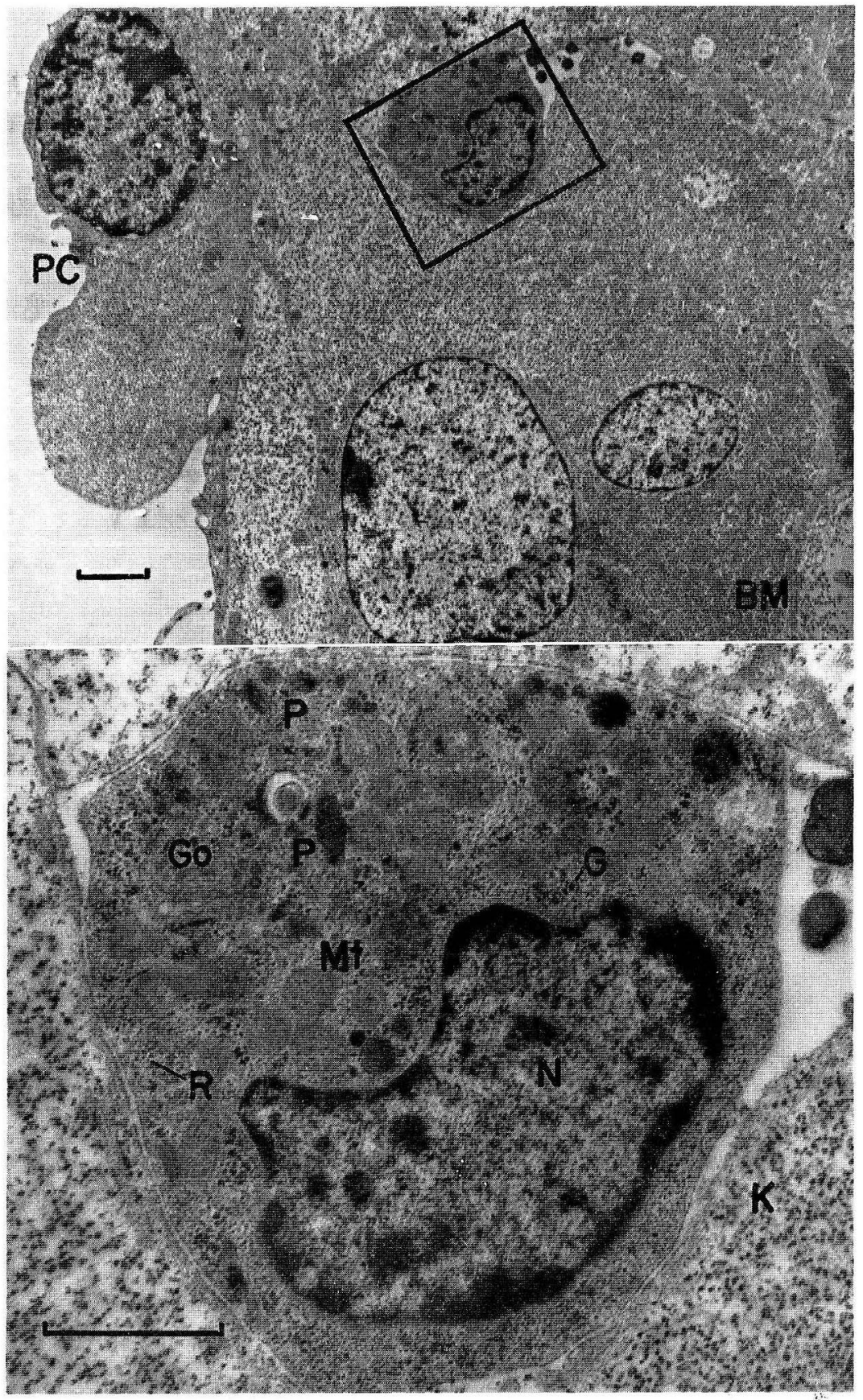

Fig. 8. Survey picture of the epidermis in limb skin of a 9 -week fetus. The earlitest melanocyte (box) located in a middle portion of the epidermis. $P C$ periderm cell show: ing globular protrusion into the amniotic cavity. $B M$ basement membrane. $\times 12,000$ Insert: Higher magnification of the area marked by box in Fig. 8 . The cytoplasm contains premelanosomes $(P)$ but no Birbeck granule. It shows an apparently higher electron density than that of neighboring keratinocytes and contains numerous free ribosomes $(R)$ and glycogen granules $(G)$. Go Golgi apparatus. Mt numerous mitochondria, $N$ indented nucleus, $K$ keratinocytes. $\quad \times 30,000$ 
definitely higher electron density than that of flanking stratum intermedium cells. There were found numerous mitochondria with a relatively electron dense matrix. and numerous free ribosomes and glycogen granules.

Most periderm cells were flattened, but some of them were thick in shape, occasionally showing globular protrusion into amniotic cavity (Fig. 8). Each of these two types often retained its nucleus which conformed to the shape of the cell body and contained a relatively large nucleolus, and well developed cytoplasmic organelles such as rough endoplasmic reticulum, Golgi apparatus, mitochondria, smooth surfaced vacuoles containing glycogen granules and dense granules, some of which seemed to be of a lipid nature (Fig. 9, 10).

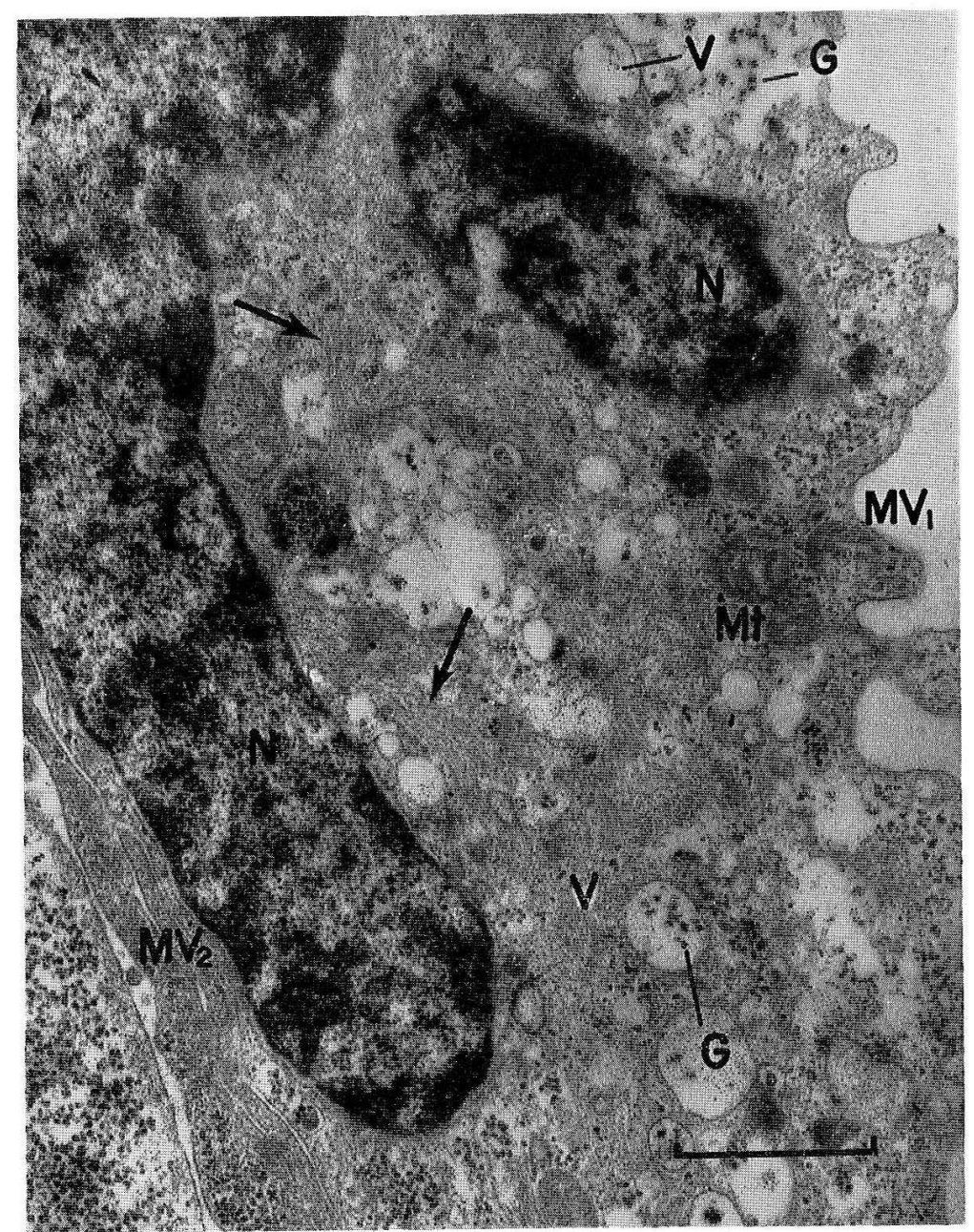

Fig. 9. Periderm cells in the same 9-week fetus as in Fig. 7. MV microvilli along the amniotic border $M V_{2}$ slender microvilli in an intercellular space. $N$ nuclei, $M t$ mitochondria. $V$ membrane-limited vacuoles containing glycogen granules $(G)$. Arrows indicate numerous tonofilaments in the cytoplasm. $\times 22,000$ 


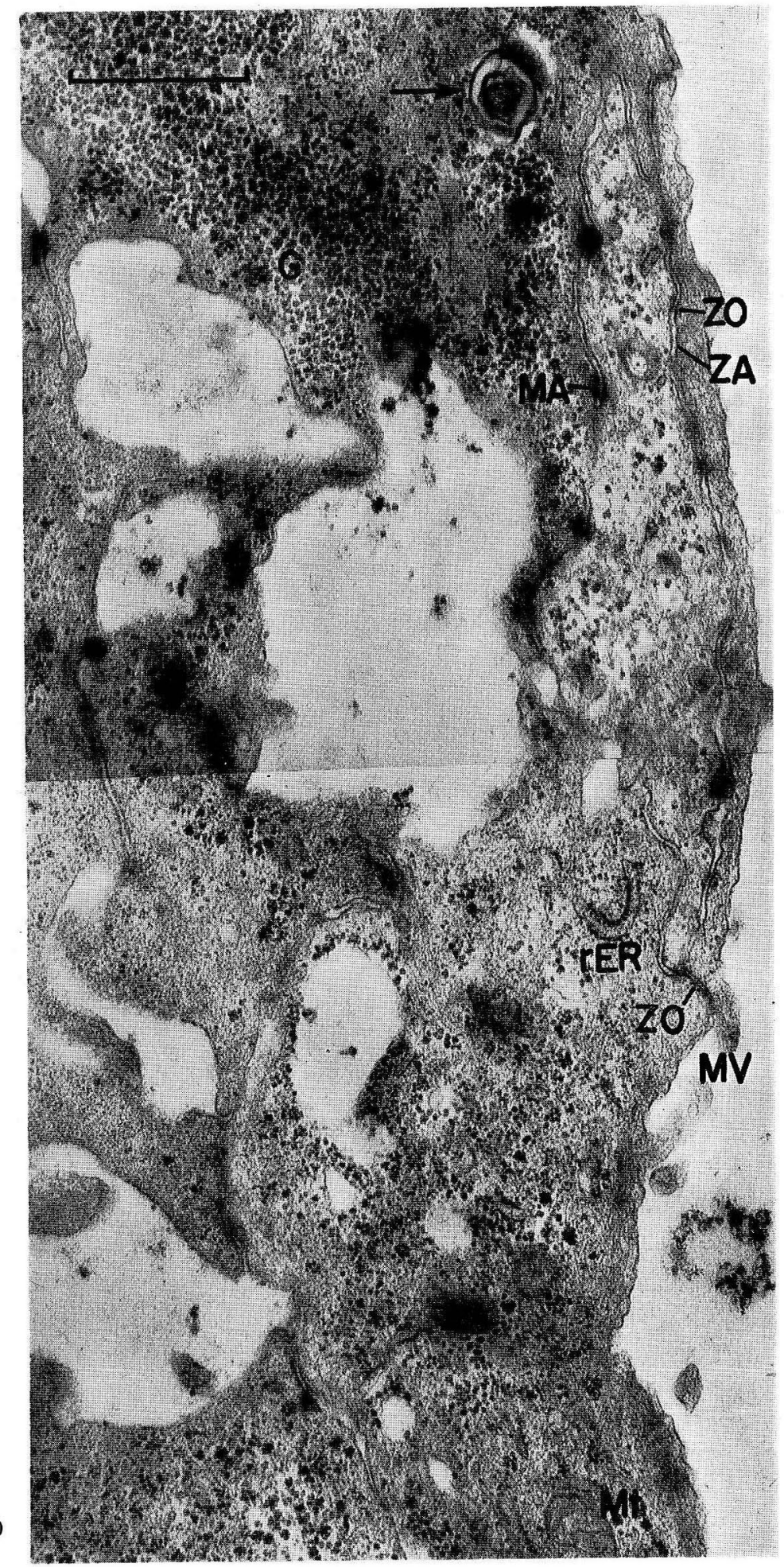


Occasional periderm cells seemed to have fewer of these organelles and contained rather well developed filamentous structures similar to tonofilaments. They were still connected by desmosomes and/or zonulae occludentes near the free surface. Their superficial borders had numerous microvilli and did not yet seem to be thickened anywhere. Cytoplasmic granules similar to those seen in developing chicken periderm described by PARAKKAL and MATOLTSY (1968) were not found in the periderm cells of this study. Keratohyalin granules were found neither in these periderm cells nor in stratum intermedium cells.

The epidermis from the limb of a 10 -week fetus $(16 \mathrm{~mm}$ long in crown-rump length) consisted of one layer of stratum germinativum, one, occasionally two, layers of stratum intermedium and one layer of periderm similar to the epidermis of the 9 -week fetuses.

Each layer of the epidermis of the 10-week fetuses showed ultrastructures essentially identical with those of each corresponding layer of the epidermis of the 9-week fetuses, though the cytoplasm of periderm cells was mostly less electron dense.

\section{Discussion}

As noted in the results, the human embryonic epidermis was found to consist mainly of a single layer, and only occasionally, two layers of cells at 6 weeks (estimated) to 7 weeks of menstrual age. At 8 weeks, we found it to consist mainly of two layers with occasional one or three layers. At 9 to 10 weeks of age, it consisted mainly of three types of layers: one layer of stratum germinativum, one or two layers of stratum intermedium and one layer of periderm, but occasionally only two layers, stratum germinativum and presumed periderm were identified.

From these results, as we presumed in the introduction, it seems likely that the double layer is not the primary state in the embryonic development of the epidermis, but is preceded by a single layer epidermis.

Passing though a bilayer state at about 8 weeks of age, the epidermis is believed to increase gradually its stratification to form three layers, stratum germinativum, stratum intermedium and periderm, by 9 weeks of age.

The bilayer epidermis in the embryo of 8 weeks of menstrual age in the study of Hoyes (1968) is believed to represent the intermediate stage between the single layer epidermis 6 to 7 weeks of age and the three layer form of 9 to 10 weeks of age. The same is the case in our embryo of 8 weeks of age.

The occasional double-layered portions in the epidermis at 6 to 7 weeks of age suggests the initiation of epidermal stratification at this stage of development. The cells of the superficial and basal layers were connected by desmosomes, sharing similar ultrastructural features, except for the difference that the former cells possessed microvillous borders while the latter did not.

By 6 to 7 weeks of age, most of the epidermal cells seemed to have finished the first step in the differentiation toward becoming keratinocytes, as indicated by the

Fig. 10. Periderm cells in the same 9-week fetus as in Fig. 7. $M V$ microvilli along the amniotic border, $Z O$ zonulae occludentes, $Z A$ zonulae adhaerentes, $M A$ maculae adhaerentes, $r E R$ rough endoplasmic reticulum, $M t$ mitochondria, $G$ aggregates of glycogen granules containing myelin figures possibly of a lipid nature. Arrow indicates a lysosomal structure. $\times 23,000$ 
fact that they were connected to one another by a relatively small number of desmosomes, despite a sparsity of tonofilaments in their cytoplasm at that age. At 9 to 10 weeks of age, these cells seemed to be in the second step in their differentiation toward becoming keratinocytes as shown by the fact that the tonofilaments definitely increased in number in their cytoplasm.

As described in the introduction, the earliest epidermal melanocytes hitherto reported are those by НАSнімото et al. (1966) in the scalp skin of a 12-week fetus. The earliest Langerhans cells in the epidermis are those which were found by BREATHNACH and Wyllie (1965 a) in the limb and face skin of a 14-week fetus.

The present finding that a melanocyte did occur in the epidermis of a 9 -week fetus evidences that the appearacne of the epidermal melanocyte is earlier than previously suggested. In the present materials, no Langerhans cells were detected in the epidermis by the embryonic age of 10 weeks, though a possibility that the cells of undetermined classification found in the epidermis of an embryo estimated to be 6 weeks of age might correspond to undifferentiated Langerhans cells cannot be excluded. It seems likely that the earliest stage when Langerhans cells appear in the epidermis may be during the period from 10 to 14 weeks of age.

\section{Summary}

Electron microscopic investigations of the epidermis of human embryos and fetuses from 6 to 10 weeks of menstrual age revealed the following:

1. The bilayer state reported by Hoyes (1968) in an 8-week fetus seemed not to represent the primary state of the epidermis in embryonic development, as the epidermis at 6 to 7 weeks of age was single-layered with occasional double-layered portions.

2. Most epidermal cells seemed to have finished the first step in their differentiation into keratinocytes by 6 to 7 weeks of age as indicated by the presence of desmosomes along their plasma membranes. A second step in this differentiation which seemed to occur at 9 to 10 weeks of age was characterized by an increase of tonofilaments in their cytoplasm.

3. A single malanocyte was found in the epidermis of a 9 -week fetus. This indicates the appearance of the mealnocyte in the epidermis to be earlier than previously reported.

4. No Langerhans cell was detected in the epidermis until 10 weeks of embryonal age, though a few cells of an undetermined cell type were found in the epidermis of an embryo estimated to be 6 weeks.

\section{ヒト皮膚表皮の胎生学的分化に関する電子顕微鏡的研究}

(内容自抄)

第 6 月経週令と推測される胎芽（全長 $5 \mathrm{~mm}$ ) から第 10 月経週令と算定される胎児 （頭尾長 $16 \mathrm{~mm}$ ）にいたる各胎令の皮膚について，その表皮細胞の分化を電子顕微鏡的 に検討し，以下の結果を得た。

1) HoYES（1968）が第 8 月経週令と算定される胎児で見た 2 細胞層から成る表皮は, 胎生最初期の状態ではなく, 単層または一部 2 層で, 大部分単層の状態が 少なくとも 6 
〜 7 週令までは先行するものと考えられる.

2）表皮構成細胞中には，6７週令ではトノフィラメントの発生は まだ見られな いが，デスモゾームは その大部分のものですでに形成されているので，そのケラチノ サイト方向への第一段階の分化を完了したものと思われる. 第 8 週令で細胞質内に痕跡 的に発生したトノフィラメントが 9 10 週では明らかな増加を示すので，この時期にケ ラチノサイト方向への第 2 段階の分化が起こるものと思われる.

3 ）従来の報告において，人胎児表皮中にメラノサイトが電顕的に見出された最早期 胎令は 12 週令であったが，本研究では 9 週令が最早期であった。

4 ) 本研究で観察した 何れの胎令の表皮にもランゲルハンス細胞は見出されなかっ た。ただし 第 6 月経週令と推定される胚芽の表皮中に，細胞型定決定しえぬ 二三個の 細胞が見られた。

\section{References}

Arey, L. B.: Developmental anatomy. Philadelphia-London, W. B. Saunders Co., 1966.

Breathnach, A. A. and L. M. Wyllie: Electron microscopy of melanocytes and Langerhans cells in human fetal epidermis at fourteen weeks. J. invest. Dermatol. 44: 51-60 (1965a).

: Fine structure of cells forming the surface layer of the epidermis in human fetuses at fourteen and twelve weeks. J. invest. Dermatol. 45: 179-189 (1965b).

Fujita, H. and C. Asagami: Electron microscopic study of the early development of human skin. In: (ed. by) R. Uyeda: Electron microscopy. Vol. II. Proc. of 6th Int. Congr. for Electron Microsc., Kyoto, Maruzen Co. Ltd., 1966. (p. 583-584).

Fujita, H., C. Asagami, T. Mori, Y. Oda, I. Arai and I. Araki: Electron microscopic studies on dermal melanocytes in human fetus skins. Acta dermatol. (Kyoto) 63: 1-16 (1968).

Hashimoto, K., B. G. Gross, R. J. BiBella and W. F. Lever: The ultrastructure of the skin of human embryos. J. invest. Dermatol. 47: 317-335 (1966).

Hoyes, A. D.: Acid mucopolysaccharide in human fetal epidermis. J. invest. Dermatol. 48: 598601 (1967).

-: Electron microscopy of the surface layer (periderm) of human foetal skin. J. Anat. 103: 321-336 (1968).

Luft, J. H.: Improvement in epoxy resin embedding methods. J. biophys. biochem. Cytol. 9: 409-414 (1961).

Millonig, G.: Advantages of a phosphate buffer for $\mathrm{OsO}_{4}$ solution in fixation. J. appl. Physics 32: 1637 (1961).

Nakamura, K., O. Saito and T. Hase: Studies on Japanese embryos at early stages of the development with special reference to their length and weight. Bull. Kobe Med. Coll. 6: 1937-1941 $(1955 / 56)$

Parakkal, P. F. and A. G. Matoltsy: An electron microscopic study of developing chick skin. J. Ultrastr. Res. 23: 403-416 (1968).

Riegel, P.: Die Fruhentwicklung der Ultrastructur in der Epidermis menschlicher Embryonen. Z. Morphol. Anthropol. 56: 195-205 (1965).

Yoshimura, Y.: Über die Fußsohlenlänge und die Handtellerbreite der japanischen Embryonen in den verschiedenen embryonalen Stadien. Organ der Nagasaki Medizinischen Gesellschaft 15: 1-9 (1937).

\author{
藤田英輔 \\ 率755 宇部市小串 1144 \\ 山口大学医学部 \\ 皮膚科学教室
}

Prof. Hidesuke Fujita

Department of Dermatology

Yamaguchi University School of Medicine

755 Ube, Japan 